\title{
Kesuksesan Karier Ditinjau dari Persepsi Pengembangan Karier dan Komitmen Karier pada Pekerja Milenial
}

\author{
Putu Aninditha Veera Lakshmi ${ }^{1}$ E Sumaryono ${ }^{2}$ \\ Fakultas Psikologi Universitas Gadjah Mada
}

\begin{abstract}
The hospitality industry is one of the fastest growing service industries with the majority of employees are millennial workers. Millennial workers concerned to successful of their career so that they are willing to leave one organization to another to realize career success. Based on that, it is important for organization to help realize employee career success through career development. Moreover, career success can also be realized by the commitment of employees to their careers. This research is a quantitative with multiple regression analysis, which aims to determine career success reviewed from perceptions of career development and career commitment. Respondents in this study are millennial workers who work in hospitality industry which are taken by quota sampling method. The results of this study state that perceptions of career development and career commitment are predictors of career success in millennial workers in hospitality industry. The influence is $44.8 \%$ on increasing career success.
\end{abstract}

Keywords: career commitment; career development; success

\begin{abstract}
Abstrak. Industri perhotelan merupakan salah satu industri jasa dengan pertumbuhan tercepat di dunia yang mayoritas karyawannya adalah pekerja milenial. Pekerja milenial sangat mementingkan kesuksesan karier sehingga ia rela meninggalkan satu organsiasi ke organisasi lain demi mewujudkan kesuksesan karier. Melihat hal tersebut, maka penting bagi suatu organisasi untuk membantu mewujudkan kesuksesan karier karyawan salah satunya melalui pengembangan karier. Selain itu, kesuksesan karier juga dapat diwujudkan dengan adanya komitmen dari karyawan terhadap kariernya. Penelitian ini adalah kuantitatif dengan analisis regresi berganda, yang bertujuan untuk mengetahui kesuksesan karier yang ditinjau dari persepsi pengembangan karier dan komitmen karier. Responden dalam penelitian ini adalah pekerja milenial yang bekerja dalam hospitality industry yang diambil dengan metode kuota sampling. Hasil penelitian ini menyatakan bahwa persepsi pengembangan karier dan komitmen karier adalah prediktor dari kesuksesan karier pada pekerja milenial di hospitality industry. Pengaruh kedua prediktor sebesar $44.8 \%$ terhadap peningkatan kesuksesan karier.
\end{abstract}

Kata kunci: kesuksesan; komitmen karier; pengembangan karier

Istilah hospitality adalah istilah dalam bahasa Inggris yang jika diterjemahkan ke dalam bahasa Indonesia berarti keramahtamahan. Sedangkan hospitality industry sendiri jika dimaknai secara keseluruhan memiliki arti industri perhotelan. Istilah perhotelan kerap disalahartikan sebagai ranah bisnis yang hanya meliputi hotel, namun sebenarnya industri perhotelan mencakup bisnis yang lebih luas dari hanya

\footnotetext{
${ }^{1}$ Korespondensi mengenai isi artikel ini dapat

dilakukan melalui anindithaveera92@gmail.com

${ }^{2}$ Atau melalui sumaryono.cendix@ugm.ac.id 
sekedar hotel. Industri perhotelan merupakan kombinasi dari usaha yang berbentuk akomodasi dan makanan dan minuman, yang secara kolektif merupakan segmen industri terbesar. Salah satu ciri khas dalam bekerja di industri ini adalah tingginya mobilitas kerja, tingginya tuntutan kerja, menantang secara fisik maupun mental, serta memiliki jam kerja yang panjang. Industri ini sangat menjunjung pelayanan dalam operasional sehari-harinya, sehingga karyawan dituntut agar dapat bekerja dalam waktu yang panjang bahkan pada hari libur dan akhir pekan. Melalui sistem shifting yang memungkinkan karyawannya untuk terus bekerja secara bergantian dalam waktu 24 jam sehari.

Melihat pentingnya peran karyawan dalam bisnis ini, maka karyawan memegang peranan kunci dalam meningkatkan kualitas layanan, memuaskan kebutuhan pelanggan dan meningkatkan loyalitas pelanggan. Saat ini mayoritas tenaga kerja di industri perhtelan berasal dari generasi Y (Gursoy, Chi \& Karadag, 2013). Generasi $Y$ atau yang kerap disebut sebagai generasi milenial adalah individu yang lahir diantara tahun 1980 hingga 1995 (Zemke, Raines \& Filipczak, 2000). Jumlah generasi $Y$ yang secara produktif bekerja di Indonesia menurut Kompas pada tahun 2016 adalah sekitar $30 \%$ dan diprediksi akan meningkat sejumlah 50\% di tahun 2020 dan segera menjadi 70\% (Rachman \& Jakob, 2016). Karakteristik umum yang dimiliki generasi $\mathrm{Y}$ pada umumnya dalah optimis, kreatif, civicminded, pro-diversity, pro-work life balance, mobilitas tinggi, butuh pengakuan dan umpan balik, menghargai bekerja dalam tim, mau belajar, mudah beradaptasi lingkungan baru, santai dan pecinta kesenangan (Zemke, Raines \& Filipczak, 2000).

Dalam berinteraksi di dunia kerja, pekerja yang digolongkan generasi $\mathrm{Y}$ atau pekerja milenial dinilai kurang memiliki komitmen dalam pekerjaan, sehingga dianggap menjadi pemicu permasalahan mengenai rendahnya loyalitas pekerja millenial terhadap perusahaan tempat mereka bekerja (Utami, 2018; Deal, 2007). Beberapa penelitian telah dilakukan untuk meneliti intensi dari perputaran kerja yang dilakukan pekerja milenial dalam industri perhotelan, namun perputaran kerja tetap terjadi dan seolah-olah tidak dapat dihentikan. Dari sekian banyak penelitian hanya memfokuskan pada hal yang dapat mengurangi intensitas perputaran kerja namun jarang penelitian dilakukan untuk mencari tujuan dari pekerja milenial itu sendiri dalam berpindah-pindah perusahaan. Maka dari itu penting untuk mengetahui apa yang diinginkan dan yang menjadi tujuan karier pekerja milenial agar dapat memanfaatkan mereka sebagai sumber daya manusia yang produktif di dalam organisasi.

Dari sekian banyak survei dan penelitian yang dilakukan beberapa tahun belakangan ini maka dapat disimpulkan bahwa pekerja milenial tidak lagi berpaku pada komitmen terhadap organisasi, melainkan terhadap kesuksesan kariernya. Pekerja milenial rela meninggalkan satu organsiasi ke organisasi lain demi kepentingan kariernya dan mewujudkan kesuksesan karier (Cicek, Karaboga \& Sehitoglu, 2016; Mooney, Harris \& Ryan, 2016; Malute, 2012). Kesuksesan karier didefinisikan lebih lanjut sebagai pencapaian nyata atau yang dirasakan individu yang diakumulasikan dari pengalaman kerja mereka (Hall, 1996; Judge et al, 1995), yang terdiri dari dua komponen yaitu kesuksesan karier nyata dan subjektif. Kesuksesan karier nyata dapat dilihat dan diobservasi dari status dan jabatan yang dimiliki seseorang, banyak promosi yang diperoleh dan jumlah gaji yang diterima setiap bulannya, sedangkan kesuksesan karier subjektif berkaitan dengan kepuasan individu itu 
sendiri terhadap karier yang dimilikinya (Judge \& Hurst, 2008).

Hampir seluruh karyawan memiliki tujuan utama yaitu menginginkan kesusksesan dalam karier mereka. Melihat betapa pentingnya kesuksesan pekerjaan dan karier bagi kehidupan setiap karyawan, maka penting bagi suatu organisasi untuk mempertimbangkan hal tersebut. Setiap organiasasi perlu mempertahankan karyawan yang sukses dalam kariernya, sebab karyawan yang sukses dalam kariernya dapat menunjukan performa yang menun-jang kebutuhan organisasi (Cicek, Karaboga \& Sehitoglu, 2016). Karyawan yang sukses dalam kariernya akan lebih puas dengan pekerjaannya, sehingga menunjukan kinerja yang lebih giat. Dukungan organisasi untuk mengembangkan karier karyawannya dapat dilihat dari persepsi pengembangan karier yang dirasakan oleh karyawan yang bekerja dala organisasi. Dubrin (1982) mejelaskan pengembangan karier sebagai aktivitas kepegawaian yang membantu pegawai-pegawai merencanakan karier masa depan mereka di perusahaan agar perusahaan dan pegawai dapat mengembangkan dirinya dengan maksimal.

Pengembangan karier dapat mengatur karier karyawan dan memastikan kesuksesan kariernya di masa depan. Penting bagi pekerja milenial untuk mempersepsikan positif pengembangan karier yang ada dalam organisasi, sebab memenuhi harapan karier generasi muda adalah langkah penting untuk penciptakan kepuasan karier dan kesuksesan karier, yang nantinya akan berdampak pada antusiasme kerja (Kong, Wang \& Fu, 2015). Faktor-faktor dalam pengembangan karier karyawan seperti peluang promosi (peningkatan status jabatan) dan pemberian penghargaan yang objektif dianggap sebagai fondasi dasar untuk kesuksesan karier karyawan seacra nyata E-JOURNAL GAMAJOP
(Amstrong \& Taylor, 2014). Kesempatan untuk mendapat peluang promosi, kenaikan jabatan maupun kenaikan kompensasi dapat dirasakan sebagai penghargaan yang diberikan organsisi kepada karyawannya. Karyawan yang merasa dihargai dan merasa ditempatkan pada posisi setara biasanya juga akan memiliki rasa puas dalam bekerja. Begitu juga dengan faktor pengembangan karier yang memungkinkan adanya mentoring dari atasan dapat membantu karyawan dalam meningkatkan keterampilan untuk menyelesaikan tugas-tugas (Anafarta \& Apaydin, 2016), sehingga dapat menumbuhkan rasa percaya diri dan kepuasan karier karyawan yang merupakan indikator kesuksesan karier subjektif (Ndung'u, 2016).

Selain persepsi terhadap pengembangan karier dalam organisasi, kesuksesan karier juga dapat diwujudkan dengan adanya komitmen dari karyawan terhadap kariernya. Memprediksi kesuksesan karier bagi seseorang merupakan faktor yang rumit, maka kesuksesan karier merupakan tanggung jawab bersama antara organisasi tempat karyawan bekerja serta individu itu sendiri (Koekemoer, 2014). Komitmen karier sebagai sikap seseorang terhadap suatu profesi atau pekerjaan (Blau, 1985).

Karyawan yang memiliki komitmen karier akan lebih banyak mengeluarkan investasi untuk kariernya dan mendorong karyawan untuk melengkapi dirinya dalam menghadapi perubahan lingkungan kerja. Lingkungan kerja dalam industri perhotelan yang dinamis mengharuskan karyawan untuk melengkapi diri dengan pengetahuan terkini agar bisa bersaing dilapangan. Seseorang yang berkomitmen terhadap kariernya akan lebih terbuka untuk mengikuti pengembangan dan pelatihan serta memperoleh pengetahuan sejalan yang akan membantunya untuk maju dalam kariernya (Sultana et al, 2016). 
Besarnya usaha yang dilakukan seseorang untuk kemajuan karier dapat menuntunnya pada performa yang lebih baik dan mampu bersaing dengan karyawan lain yang ada dalam organisasi. Pada akhirnya hal tersebut akan mengarah pada peningkatan kompensasi maupun status jabatan yang lebih tinggi, yang merupakan indikator dari kesuksesan karier nyata. Selain itu, karyawan yang memiliki komitmen karier juga cenderung termotivasi untuk bekerja secara giat dan mengeluarkan usaha terbaiknya dalam menyelesaikan permasalahan yang ada dalam pekerjaan. Maka dari itu, seseorang yang memiliki komitmen karier juga dapat merasa lebih puas akan karier maupun pekerjaannya dibandingkan dengan seseorang yang kurang berkomitmen.

Melihat beberapa penelitian yang dilakukan dapat disimpulkan bahwa kesuksesan karier dapat diwujudkan melalui persepsi pengembangan karier yang positif dan komitmen karier yang tinggi. Penelitian ini akan menunjukan bahwa karyawan yang memiliki persepsi pengem-bangan karier yang positif dan komitmen karier yang tinggi juga memiliki kesuksesan yang tinggi dalam kariernya, sehingga penelitian ini akan merujuk pada daerah Bali sebagai praktik terbaik hospitality industry di Inodnesia. Selain karena maraknya industry hospitality yang tersebar diseluruh pelosok pulau, karyawan hospitality di Bali juga terkenal dengan karakteristiknya dalam bekerja yang menjunjung tinggi keramahtamahan. Bekerja dalam hospitality akan menghasilkan nilai-nilai yang berbeda pada masyarakat Bali (Astina, Bendesa \& Wiranatha, 2017), sehingga memungkinkan karyawan untuk mewujudkan kesuksesan karier yang tinggi.

Berdasarkan hal yang telah dipaparkan tersebut, sehingga kesuksesan karier dapat diwujudkan dengan adanya persepsi pengembangan karier dan komitmen karier yang dimiliki oleh setiap karyawan terhadap karier yang ia jalani. Oleh karena itu, hipotesis penelitian ini adalah persepsi pengembangan karier dan komitmen karier merupakan prediktor dari kesuksesan karier.

\section{Metode}

Penelitian ini menggunakan dua jenis variabel, yaitu variabel independen sebagai prediktor dan variabel independen sebagai variabel kritera. Variabel prediktor dalam penelitian ini terdiri dari persepsi pengembangan karier dan komitmen karier. Persepsi pengembangan karier adalah proses penafsiran individu terhadap aktivitas kekaryawanan yang dapat membantu dan memajukan karyawan untuk meningkatkan pengetahuan atau keterampilan yang mendukung kelancaran pelaksanaan tugas-tugas saat ini maupun terkait dengan rencana karier masa depan, agar organisasi dan karyawan yang bersangkutan dapat mengembangkan diri secara maksimum, yang terdiri dari aspek perlakuan yang adil dalam organisasi, kepedulian atasan langsung, informasi mengenai peluang kenaikan jabatan, minat untuk dipromosikan dan kepuasan karier, yang diukur dengan menggunakan skala persepsi pengembangan karier. Sedangkan, komitmen karier adalah sikap dan motivasi seseorang untuk bekerja dalam karier yang menjadi pilihannya, yang terdiri dari aspek identitas karier, perencanaan karier dan ketahanan karier, yang diukur dengan menggunakan skala komitmen karier. Variabel kriteria adalah kesuksesan karier yaitu persepsi individu mengenai pencapaian nyata atau yang dirasakannya terhadap kepuasan dan kemajuan kariernya yang diakumulasikan dari pengalaman kerja mereka, yang meliputi kesuksesan karier secara nyata dan subjektif, yang terdiri dari aspek kesuksesan karier nyata dan kesuksesan karier subjektif. 
Penelitian ini adalah penelitian kuantitatif. Populasi yang ditargetkan dalam penelitian ini adalah pekerja milenial yang bekerja dalam industri perhotelan, yang diambil dengan metode non probability sampling, dengan teknik kuota sampling. Kuota sampling adalah teknik untuk menentukan sampel yang memiliki ciri-ciri tertentu sampai jumlah (kuota) yang diinginkan terpenuhi (Sugiyono, 2007). Kuota yang ditetapkan dalam penelitian ini adalah 200. Adapun kriteria responden penelitian ini yaitu: (1) Karyawan pria dan wanita, yang merupakan generasi millenial yaitu individu yang lahir diantara tahun 1980 hingga 1995 (Zemke, Raines, \& dan Filipczak, 2000). (2) Karyawan memiliki pendidikan minimal SMA atau SMK sederajat agar dapat merespon kuisioner dengan tepat. (3) Karyawan memiliki latar belakang pendidikan dalam bidang hospitality industry, sebab individu yang memiliki latar belakang pendidikan yang sesuai dengan kariernya memiliki kesempatan lebih besar untuk bekerja dalam bidang yang sejalan serta untuk sukses (Koekemoer, 2014). (4) Karyawan yang bekerja di industri perhotelan yang termasuk didalamnya adalah hotel, motel, resort, villa, restoran dan penyedia akomodasi perjalanan. Adapun khusus yang berkarier di satu daerah yang sama yang dalam penelitian ini akan diambil di daerah Bali, sebab industri perhotelan di Bali memiliki laju pertumbuhan yang pesat disbanding daerah lainnya. Selain itu, masyarakat Bali juga dikenal dengan keramahtamahan dalam melayani bahkan ketika bekerja, maka dari itu berkarier dalam industri perhotelah telah menjadi tujuan utama dari masyarakat Bali.

Pengumpulan data dilakukan menggunakan skala psikologi dengan model skala Likert. Aitem-aitem dalam skala terdiri dari lima alternatif pilihan jawaban, yaitu untuk aitem favorable sangat tidak sesuai $(\mathrm{STS})=$ skor 1 , tidak sesuai $(\mathrm{TS})=$ skor 2, netral $(\mathrm{N})=$ skor 3, sesuai $(\mathrm{S})=$ skor 4 , dan sangat sesuai $(\mathrm{SS})=$ skor 5 . Sedangkan untuk aitem unfavorable berlaku sebaliknya. Skala yang digunakan adalah sebagai berikut.

\section{Skala Kesuksesan Karier}

Skala kesuksesan karier yang digunakan dalam penelitian ini dimodifikasi dari penelitian Noviani (2018), mengacu pada teori Judge \& Hurst (2008) yang terdiri dari 2 aspek yaitu kesuksesan karier nyata dan kesuksesan karier subjektif. Distribusi aitem pada skala kesuksesan karier dijabarkan pada tabel 1 .

Tabel 1.

Blue Print Skala Kesuksesan Karir

\begin{tabular}{cccc} 
No. & \multicolumn{1}{c}{ Aspek } & Aitem & Jumlah \\
\hline 1 & Kesuksesan karir nyata & $2,4,6,8,10,12,14,16,18,20$ & 10 \\
\hline 2 & Kesuksesan karir subjektif & $1,3,5,7,9,11,13,15,17,19$ & 10 \\
\hline \multicolumn{2}{r}{ Jumlah } & 20 \\
\hline
\end{tabular}

untuk akomodasi penginapan di fokuskan pada hotel, resort atau villa yang memiliki bintang 3 ke atas yang biasanya memiliki jenjang karier yang lebih jelas. (5) Karyawan memiliki masa kerja minimal 2 tahun dari awal saat mulai berkarier dalam bidang industri perhotelan. (6) Karyawan E-JOURNAL GAMAJOP

\section{Skala Persepsi Pengembangan Karier}

Skala persepsi pengembangan karier disusun sendiri oleh peneliti mengacu pada teori Davis \& Werther (1996) yang terdiri dari lima aspek yaitu perlakuan yang adil dalam organisasi, kepedulian atasan 
langsung, informasi mengenai peluang kenaikan jabatan, minat untuk dipromosikan, dan kepuasan karier. Distribusi aitem pada skala persepsi pengembangan karier dijabarkan pada tabel 2. regresi berganda untuk meramalkan keadaan (naik turunnya) variabel kriteria, dengan dua variabel prediktor sebagai faktor prediktor dimanipulasi (dinaik turunkan nilainya) (Sugiyono, 2007).

Tabel 2.

Blue Print Skala Persepsi Pengembangan Karir

\begin{tabular}{clccc}
\multirow{2}{*}{ No } & \multicolumn{1}{c}{ Aspek } & \multicolumn{2}{c}{ Aitem } & \multirow{2}{*}{ Jumlah } \\
\cline { 3 - 4 } & Pavorable & Unfavorable & \\
\hline 1 & Perlakuan yang adil dalam organisasi & $4,8,12$ & 19 & 4 \\
\hline 2 & Kepedulian atasan langsung & 2,10 & 18,15 & 4 \\
\hline 3 & $\begin{array}{l}\text { Informasi mengenai peluang kenaikan } \\
\text { jabatan }\end{array}$ & 1,7 & 11,17 & 4 \\
\hline 4 & Minat untuk dipromosikan & 6,14 & 9,20 & 4 \\
\hline 5 & Kepuasan karir & 5,13 & 3,16 & 4 \\
\hline \multicolumn{2}{c}{ Jumlah } & & 20 \\
\hline
\end{tabular}

Tabel 3.

Blue Print Skala Komitmen Karir

\begin{tabular}{clccc}
\multirow{2}{*}{ No } & \multirow{2}{*}{ Aspek } & \multicolumn{2}{c}{ Aitem } & \multirow{2}{*}{ Jumlah } \\
\cline { 3 - 5 } & & Favorable & Unfavorable & \\
\hline 1 & Identitas karir & $1,6,12$ & $4,8,14$ & 6 \\
\hline 2 & Perencanaan karir & $3,10,15$ & 5,13 & 5 \\
\hline 3 & Ketahanan karir & 7,9 & 2,11 & 4 \\
\hline & & \multicolumn{3}{c}{15} \\
\hline
\end{tabular}

Skala Komitmen Karier

Skala komitmen karier disusun sendiri oleh peneliti mengacu pada teori Carson \& Bodeian (1994) yang terdiri dari tiga aspek yaitu identitas karier, perencanaan karier dan ketahanan karier. Distribusi aitem pada skala komitmen karier dijabarkan pada tabel 3 .

Prosedur penelitian dilakukan dalam tiga tahap yaitu (1) tahap persiapan penelitian dengan menyiapkan proposal dan surat ijin penelitian, (2) tahap pengumpulan data yang dilakukan sebanyak dua kali yaitu pada proses uji coba skala dan pengambilan data penelitian, (3) tahap analisis data yang dilakukan dengan analisis statistik. Metode analisis data yang digunakan pada data penelitian adalah

\section{Hasil}

Adapun sebelum melakukan analisis data, terlebih dahulu dilakukan uji validitas dan reliabilitas dari alat ukur (skala) yang digunakan. Uji validitas dalam penelitian ini dilakukan dengan validitas isi dengan analisis rasional dan validitas konstrak dengan formulasi Aiken $\mathrm{V}$ dengan batas nilai 0,61 (Aiken, 1985). Pengujian validitas dilakukan mulai dari tanggal 11 Juni 2018 hingga 23 Juni 2018 dengan meminta penilaian dari rater yaitu mahasiswa Magister Psikologi Profesi bidang Psikologi Industri dan Organisasi sebanyak 25 orang. Hasil pengujian memperlihatkan bahwa validitas pada skala kesuksesan karier 
Tabel 4.

Karakteristik Subjek

\begin{tabular}{cclcc} 
No. & Berdasarkan & \multicolumn{1}{c}{ Keterangan } & Jumlah & Persentase (\%) \\
\hline 1 & Jenis Kelamin & Laki-laki & 113 & $56.2 \%$ \\
\hline & & Perempuan & 88 & $43.8 \%$ \\
\hline 2 & Pendidikan & Diploma & 152 & $75.6 \%$ \\
\hline & & S1 & 42 & $20.9 \%$ \\
\hline & & S2 & 7 & $3.5 \%$ \\
\hline 3 & Masa Kerja & $\leq 5$ tahun & 143 & $71.1 \%$ \\
\hline & & $6-10$ tahun & 45 & $22.4 \%$ \\
\hline & & $\geq 10$ tahun & 13 & $6.5 \%$ \\
\hline 4 & Jenis Perusahaan & Hotel & 149 & $74.1 \%$ \\
\hline & & Resort/ villa & 3 & $1.5 \%$ \\
\hline & & Restoran & 49 & $24.4 \%$ \\
\hline
\end{tabular}

Tabel 5.

Deskripsi Data Penelitian

\begin{tabular}{cccccccccccc} 
Variabel & $\mathbf{N}$ & \multirow{N}{*}{$\begin{array}{l}\text { N of } \\
\text { item }\end{array}$} & \multicolumn{4}{c}{ Data Hipotetik } & \multicolumn{4}{c}{ Data Empirik } \\
\cline { 3 - 12 } & & & \multicolumn{4}{c}{ Skor } & \multicolumn{4}{c}{ Skor } \\
\cline { 3 - 12 } & & & Min & Max & Mean & SD & Min & Max & Mean & SD \\
\hline 1 & 201 & 20 & 20 & 100 & 60 & 13.33 & 45 & 100 & 72.98 & 10.636 \\
\hline 2 & 201 & 20 & 20 & 100 & 60 & 13.33 & 41 & 97 & 69.53 & 10.620 \\
\hline 3 & 201 & 15 & 15 & 75 & 45 & 10 & 36 & 71 & 52.72 & 7.159 \\
\hline
\end{tabular}

Keterangan variabel:

1: Kesuksesan Karir

2: Persepsi Pengembangan Karir

3: Komitmen Karir

bergerak pada angka $0,65-0,81$, pada skala persepsi pengembangan karier bergerak pada angka 0,71-0,82, dan pada skala komitmen karier bergerak pada angka 0,73 0,84 . Berdasarkan analisis Aiken $\mathrm{V}$ tidak ditemukan aitem yang memiliki nilai dibawah nilai yang distandarkan yaitu 0,61 , sehingga tidak ada aitem yang gugur dari ketiga skala yang digunakan.

Pengujian dilanjutkan dengan uji coba skala penelitian mulai dari tanggal 25 Juni 2018 hingga tanggal 5 Juli 2018. Terdapat sebanyak 33 orang responden yang digunakan untuk uji coba skala penelitian. Melalui analisis Alpha Cronbach didapatkan nilai koefisien reliabilitas skala kesuksesan Karier adalah sebesar 0,935 dengan nilai korelasi aitem total bergerak dari rentang angka 0,336 - 0,859, skala Persepsi Pengembangan Karier sebesar E-JOURNAL GAMAJOP
0,885 dengan nilai korelasi aitem total bergerak dari rentang angka 0,319-0,732, dan skala Komitmen Karier adalah sebesar 0,844 dengan nilai korelasi aitem total bergerak dari rentang angka 0,332-0,618.

Berdasarkan analisis tidak terdapat aitem yang memiliki nilai dibawah standar, sehingga tidak ada aitem yang gugur dari skala Kesuksesan Karier, Persepsi Pengembangan Karier dan Komitmen Karier dalam proses uji coba. Peneliti kemudian melakukan pengambilan data penelitian mulai dari tanggal 27 Juni 2018 - 20 Juli 2018 di beberapa perusahaan di Bali, dengan banyak responden yang terkumpul adalah 201. Adapun deskripsi data penelitian dijabarkan pada tabel 4 .

Pada tabel 5 dijabarkan mean hipotetik dan mean empirik dari masing-masing skala. Mean hipotetik atau mean teoritis 
Tabel 6.

Formula Kategorisasi Skor Peneltian

\begin{tabular}{cc} 
Formula Kategorisasi & Kategorisasi Skor \\
\hline$X \leq(\mu-1,5 \sigma)$ & Sangat Rendah \\
\hline$(\mu-1,5 \sigma)<X \leq(\mu-0,5 \sigma)$ & Rendah \\
\hline$(\mu-0,5 \sigma)<X \leq(\mu+0,5 \sigma)$ & Sedang \\
\hline$(\mu+0,5 \sigma)<X \leq(\mu+1,5 \sigma)$ & Tinggi \\
\hline$(\mu+1,5 \sigma)<X$ & Sangat Tinggi \\
\hline
\end{tabular}

Keterangan: $\mu$ : Nilai Rata-rata (mean) ; $\sigma:$ Standar Deviasi (SD)

Tabel 7.

Kategorisasi Skor Skala Kesuksesan Karir

\begin{tabular}{cccc} 
Rentang & Kategorisasi Skor & Jumlah & Persentase (\%) \\
\hline$\leq 40.01$ & Sangat Rendah & 0 & $0 \%$ \\
\hline $40.01<\mathrm{X} \leq 53.34$ & Rendah & 6 & $3 \%$ \\
\hline $53.34<\mathrm{X} \leq 66.66$ & Sedang & 47 & $23.4 \%$ \\
\hline $66.66<\mathrm{X} \leq 79.99$ & Tinggi & 97 & $48.3 \%$ \\
\hline $79.99<\mathrm{X}$ & Sangat Tinggi & 51 & $25.4 \%$ \\
\hline \multicolumn{5}{c}{ Jumlah } & 201 & $100 \%$ \\
\hline
\end{tabular}

adalah rata-rata skor penelitian yang diperoleh dari angka yang menjadi titik tengah skala penelitian. Sedangkan mean empirik adalah rata-rata skor dari data penelitian yang didapat dari skor subjek di lapangan (Sugiyono, 2007). Pada ketiga skala diperoleh mean hipotetik lebih kecil dari mean empirik. Hal ini menunjukan bahwa rata-rata subjek penelitian memiliki tingkat Kesuksesan Karier yang tinggi, tingkat Persepsi Pengembangan Karier yang tinggi dan tingkat Komitmen Karier yang tinggi.

Peneliti juga melakukan kategorisasi dengan menempatkan responden ke dalam kelompok yang terpisah berdasarkan atribut yang diukur. Kategorisasi skor skala penelitian dibagi ke dalam 5 kategori yaitu sangat rendah, rendah, sedang, tinggi, dan sangat tinggi. Tabel 6 menunjukkan formula yang digunakan dalam pengkategorian skor penelitian.

Berdasarkan formula kategorisasi skor diatas peneliti melakukan kategorisasi pada variabel Kesuksesan Karier, Persepsi Pengembangan Karier dan Komitmen
Karier. Tabel 7 merupakan rincian kategorisasi skor pada masing-masing skala.

Berdasarkan hasil analisis kategorisasi skor pada skala Kesuksesan Karier pada tabel 7, dapat dilihat bahwa mayoritas skor responden berada pada kategori tinggi yaitu sebanyak 97 (48\%). Hal ini menunjukan bahwa sebagian besar responden memiliki persepsi kesuksesan karier yang baik.

Berdasarkan hasil analisis kategorisasi skor pada skala Persepsi Pengembangan Karier di tabel 8 dapat dilihat bahwa mayoritas skor responden berada pada kategori tinggi yaitu sebanyak 82 (40.8\%). Hal ini menunjukan bahwa sebagian besar responden mempersepsikan pengembangan karier yang ada dalam perusahaan secara baik.

Berdasarkan hasil analisis kategorisasi skor pada skala Komitmen Karier di tabel 9 dapat dilihat bahwa mayoritas skor responden berada pada kategori tinggi yaitu sebanyak 96 (47.8\%). Hal ini menunjukan bahwa sebagian besar responden memiliki komitmen karier yang tinggi. 
Tabel 8.

Kategorisasi Skor Skala Persepsi Pengembangan Karir

\begin{tabular}{cccc} 
Rentang & Kategorisasi Skor & Jumlah & Persentase (\%) \\
\hline$\leq 40.01$ & Sangat Rendah & 0 & $0 \%$ \\
\hline $40.01<\mathrm{X} \leq 53.34$ & Rendah & 10 & $5 \%$ \\
\hline $53.34<\mathrm{X} \leq 66.66$ & Sedang & 77 & $38.3 \%$ \\
\hline $66.66<\mathrm{X} \leq 79.99$ & Tinggi & 82 & $40.8 \%$ \\
\hline $79.99<\mathrm{X}$ & Sangat Tinggi & 32 & $15.9 \%$ \\
\hline \multicolumn{4}{c}{ Jumlah } \\
\hline
\end{tabular}

Tabel 9.

Kategorisasi Skor Skala Komitmen Karir

\begin{tabular}{cccc} 
Rentang & Kategorisasi Skor & Jumlah & Persentase (\%) \\
\hline$\leq 30$ & Sangat Rendah & 0 & $0 \%$ \\
\hline $30<\mathrm{X} \leq 40$ & Rendah & 6 & $3 \%$ \\
\hline $40<\mathrm{X} \leq 50$ & Sedang & 72 & $35.8 \%$ \\
\hline $50<\mathrm{X} \leq 60$ & Tinggi & 96 & $47.8 \%$ \\
\hline $60<\mathrm{X}$ & Sangat Tinggi & 27 & $13.4 \%$ \\
\hline \multicolumn{4}{c}{ Jumlah } \\
\hline
\end{tabular}

Tabel 10.

Hasil Uji Normalitas

\begin{tabular}{lccc}
\multicolumn{1}{c}{ Variabel } & P & Ketentuan & Keterangan \\
\hline Kesuksesan Karir & 0,062 & $\mathrm{p}>0,05$ & Normal \\
\hline Persepsi Pengembangan Karir & 0,051 & $\mathrm{p}>0,05$ & Normal \\
\hline Komitmen Karir & 0,014 & $\mathrm{p}<0,05$ & Normal \\
\hline
\end{tabular}

Sebelum melakukan uji hipotesis, penelitian ini melakukan uji asusmsi yaitu normalitas, uji linieritas dan uji multikolinieritas. Perhitungan uji normalitas skala penelitian dapat dilihat dari tabel 10.

Berdasarkan tabel 10 dapat dilihat bahwa variabel Kesuksesan Karier memiliki nilai $p$ sebesar $0,062(p>0,05)$ dan variabel Persepsi Pengembangan Karier memiliki nilai $\mathrm{p}$ sebesar $0,051 \quad(\mathrm{p}>0,05)$, maka dari itu dapat diartikan bahwa kedua variabel memiliki distribusi normal. Sedangkan untuk variabel Komitmen Karier memiliki nilai $p$ sebesar 0,014 $(\mathrm{p}<0,05)$. Meskipun demikian, disebabkan oleh jumlah sampel yang diambil dalam penelitian ini adalah 201 maka distribusi data pada variabel Komitmen Karier dapat dikatakan normal. Mengacu pada Vaus (2002) yang menjelaskan bahwa penelitian yang mengambil jumlah sampel lebih dari
100 sudah dapat dikatakan memiliki data yang berdistribusi normal. Selanjutnya perhitungan uji linieritas skala penelitian dapat dilihat dari tabel 11.

Berdasarkan hasil uji linieritas dapat disimpulkan bahwa variabel Persepsi Pengembangan Karier dan Komitmen Karier masing-masing memiliki hubungan yang linier dengan variabel Kesuksesan Karier. Selanjutnya, pengujian multikolinieritas variabel penellitian adalah sebagai berikut.

Berdasarkan hasil uji multikolinieritas diperoleh bahwa nilai tolerance kedua variabel berada diatas 0,1 yaitu 0,514 . Begitu juga dengan nilai VIF kedua variabel berada dibawah 10 yaitu 1,946. Hal ini menunjukan bahwa tidak ada gejala multikolinieritas diantara variabel Persepsi 
Pengembangan Karier dan Komitmen Karier.
Setelah mengetahui hasil Uji Signifikansi Garis Regresi, hubungan antar variabel -

Tabel 11.

Hasil Uji Linieritas

\begin{tabular}{|c|c|c|c|c|}
\hline Variabel & $\mathbf{F}$ & $\mathbf{P}$ & Ketentuan & Keterangan \\
\hline $\mathrm{KS}(\mathrm{Y}) * \operatorname{PPK}(\mathrm{X} 1)$ & 1,323 & 0,106 & $p>0,05$ & Linier \\
\hline $\mathrm{KS}(\mathrm{Y}) * \mathrm{KK}(\mathrm{X} 2)$ & 0,997 & 0,481 & $p>0,05$ & Linier \\
\hline
\end{tabular}

Keterangan:

KS: Kesuksesan Karir

PPK: Persepsi Pengembangan Karir

KK: Komitmen Karir

Tabel 12.

Hasil Uji Multikolinieritas

\begin{tabular}{lcc}
\multicolumn{1}{c}{ Variabel } & Tolerance & VIF \\
\hline Persepsi Pengembangan Karir & 0,514 & 1,946 \\
\hline Komitmen Karir & 0,514 & 1,946 \\
\hline
\end{tabular}

Tabel 13.

Uji Signifikansi Garis Regresi

\begin{tabular}{lccccc}
\multicolumn{1}{c}{ Model } & Sum of Squares & df & Mean Square & F & Sig \\
\hline Regression & 10143,555 & 2 & 5071,777 & 80,450 & $0,000^{\mathrm{b}}$ \\
\hline Residual & 12482,366 & 198 & 63,042 & & \\
\hline Total & 22625,920 & 200 & & & \\
\hline
\end{tabular}

a. Dependent Variable: Kesuksesan Karir

b. Predictors: (Constant), Komitmen Karir, Persepsi Pengembangan Karir

Setelah seluruh uji asumsi terpenuhi, maka selanjutnya dilakukan pengujian hipotesis dengan menggunakan metode analisis regresi berganda. Hasil analisis dari regresi berganda dijabarkan pada tabel 13 .

Pada uji signifikansi garis regresi diperoleh F Hitung sebesar 80.450 dengan nilai signifikansi 0.000 . Oleh karena nilai signifikansi lebih kecil dari $0.05(\mathrm{p}<0.05)$, maka hal ini menunjukan bahwa model regresi dapat dipercaya untuk meramalkan kontribusi variabel prediktor terhadap variabel kriteria. Artinya hipotesis dalam penelitian ini diterima yaitu variabel Persepsi Pengembangan Karier dan Komitmen Karier secara bersama-sama berpengaruh terhadap Kesuksesan Karier, dengan kata lain variabel Persepsi Pengembangan Karier dan Komitmen Karier merupakan prediktor dari variabel Kesuksesan Karier. prediktor dan kriteria dapat dilihat pada hasil Signifikansi Parameter Individual di tabel 14.

Melalui tabel 14 pada nilai koefisien regresi (B) dapat dilihat arah hubungan variabel prediktor yaitu Persepsi Pengembangan Karier dan Komitmen Karier secara bersama-sama. Pada kolom B (Unstandardized Coefficients) variabel Persepsi Pengembangan Karier dan Komitmen Karier masing-masing menunjukkan angka koefisien regresi sebesar positif $(+)$ 0.318 dan (+) 0.606. Tanda positif memiliki arti bahwa hubungan antar variabel adalah searah. Artinya semakin tinggi variabel Persepsi Pengembangan Karier dan Komitmen Karier maka semakin tinggi pula Kesuksesan Karier. Pada nilai signifikansi pada variabel Persepsi Pengembangan Karier dan Komitmen Karier adalah sebesar 
Tabel 14.

Uji Signifikansi Parameter Individual

\begin{tabular}{lccccc}
\multicolumn{1}{c}{ Model } & \multicolumn{2}{c}{$\begin{array}{c}\text { Unstandardized } \\
\text { Coefficients }\end{array}$} & $\begin{array}{c}\text { Standardized } \\
\text { Coefficients }\end{array}$ & t & Sig \\
\cline { 2 - 5 } & $\mathbf{B}$ & Std. Error & Beta & & \\
\hline (Constant) & 18,890 & 4,316 & & 4,376 & 0,001 \\
\hline Persepsi Pengembangan Karir & 0,318 & 0,074 & 0,318 & 4,314 & 0,001 \\
\hline Komitmen Karir & 0,606 & 0,109 & 0,408 & 5,542 & 0,001 \\
\hline
\end{tabular}

a.Dependent Variable: Kesuksesan Karir

Tabel 15.

Sumbangan Efektif Masing-Masing Variabel

\begin{tabular}{lcccc}
\multicolumn{1}{c}{ Model } & \multicolumn{2}{c}{$\begin{array}{c}\text { Unstandardized } \\
\text { Coefficients }\end{array}$} & $\begin{array}{c}\text { Standardized } \\
\text { Coefficients }\end{array}$ & Correlations \\
\cline { 2 - 5 } & $\mathbf{B}$ & Std. Error & Beta & Zero Order \\
\hline (Constant) & 18,890 & 4.316 & & \\
\hline Persepsi Pengembangan Karir & 0,318 & 0,074 & 0,318 & 0,602 \\
\hline Komitmen Karir & 0,606 & 0,109 & 0,408 & 0,630 \\
\hline
\end{tabular}

$0.001 \quad(\mathrm{p}<0.05)$. Hal ini berarti variabel Persepsi Pengembangan Karier Komitmen Karier berpengaruh secara signifikan terhadap variabel Kesuksesan Karier. Pengaruh dalam hubungan ini dapat diyakini sebagai hubungan sebab akibat dan bukan merupakan gejala random. Dapat diramalkan dengan setiap adanya peningkatan 1 nilai dari Persepsi Pengembangan Karier dan Komitmen Karier, maka akan terjadi peningkatan pada Kesuksesan Karier. Hal ini dapat diketahui dari fungsi persamaan garis regresi sebagai berikut.

$\mathrm{Y}=\mathrm{a}+\mathrm{b} \mathrm{X} 1+\mathrm{b}$ X2

$\mathrm{Y}=18,890+(0,318) \mathrm{X} 1+(0,606) \mathrm{X} 2$

Selanjutnya besarnya sumbangan efektif kedua variabel prediktor terhadap variabel kriteria adalah 0,448 . Hal ini berarti bahwa variabel Persepsi Pengembangan Karier dan Komitmen Karier secara bersama-sama memberikan sumbangan efektif terhadap variabel Kesuksesan Karier sebesar $44.8 \%$. Besarnya sumbangan efektif pada masing-masing variabel prediktor juga dapat diketahui dengan cara mengalikan nilai Beta dengan Zero Order (nilai korelasi) antar variabel. Tabel 15 menjabarkan sumbangan efektif masing- masing variabel prediktor terhadap variabel kriteria.

Berdasarkan tabel 15 dapat dihasilkan bahwa sumbangan efektif variabel Persepsi Pengembangan Karier terhadap Kesuksesan Karier secara parsial adalah sebesar 0,1914 atau 19,14\%. Sedangkan untuk variabel Komitmen Karier terhadap Kesuksesan Karier secara parsial adalah sebesar 0,2570 atau 25,70\%.

Analisis tambahan juga dilakukan dalam penelitian ini untuk melakukan uji beda terhadap data demografi jenis kelamin yang telah didapat melalui penyebaran skala. Uji beda yang dilakukan akan melihat apakah terdapat perbedaan antara data demografi jenis kelamin yang dianalisis terhadap Kesuksesan Karier pekerja milenial yang bekerja di hospitality industry. Melalui analisis uji beda yang dilakukan dengan Independent Sample $T$ Test, hasil yang diperoleh menunjukan nilai $p=0,185(p>0,05)$. Hal ini menunjukan bahwa tidak ada perbedaan yang signifikan antara kesuksesan karier pekerja milenial laki-laki dan wanita pada hospitality industry. 


\section{Diskusi}

Berdasarkan analisis yang dilakukan menggunakan analisis regresi berganda, maka dinyatakan bahwa hipotesis dalam penelitian ini diterima yaitu Persepsi Pengembangan Karier dan Komitmen Karier merupakan prediktor terhadap Kesuksesan Karier pada pekerja milenial di hospitality industry. Diterimanya hipotesis tersebut dilihat dari hasil analisis uji signifikansi garis regresi yang menunjukan nilai $F$ sebesar 80.450 dengan nilai signifikansi $\mathrm{p}=0.000(\mathrm{p}<0.05)$. Hal tersebut menjelaskan bahwa variabel Persepsi Pengembangan Karier dan Komitmen Karier secara bersama-sama memiliki peran yang signifikan dalam peningkatan Kesuksesan Karier pada pekerja milenial di hospitality industry. Hubungan yang terjadi adalah hubungan yang positif, artinya semakin tinggi Persepsi Pengembangan Karier dan Komitmen Karier yang dimiliki karyawan, maka semakin tinggi pula Kesuksesan Karier karyawan. Begitu juga sebaliknya, apabila karyawan mengalami penurunan terhadap Persepsi Pengembangan Karier dan Komitmen Karier, maka semakin rendah pula Kesuksesan Karier yang dimiliki karyawan tersebut.

Pengaruh Persepsi Pengembangan Karier dan Komitmen Karier adalah sebesar $44.8 \%$ terhadap peningkatan maupun penurunan Kesuksesan Karier pada pekerja milenial di hospitality industry. Apabila dilihat dari analisis masing-masing variabel, secara terpisah variabel Persepsi Pengembangan Karier dapat berperan terhadap Kesuksesan Karier sebesar 19.4\%, sedangkan Komitmen Karier dapat berperan terhadap Kesuksesan Karier sebesar $25.70 \%$. Temuan penelitian ini menegenai peran persepsi pengembangan karier terhadap kesuksesan karier karyawan sejalan dengan penelitian yang dilakukan oleh $\mathrm{Ng}$ dan Feldman (2014);
Pasha, Hamid dan Shahzad (2017); Koekemoer (2014); Alzyoud (2017).

Penelitian ini bertempatkan di provinsi Bali, Indonesia. Seluruh subjek dalam penelitian ini merupakan pekerja milenial yang bekerja dalam berbagai industri hospitality yang beroperasi di daerah Bali. Bekerja dalam industry hospitality merupakan keunggulan bagi masyarakat Bali, sebab kawasan pulau Bali sendiri merupakan sektor pariwisata terbesar yang ada di Indonesia. Berbagai jenis industri ini tersebar luas diseluruh pelosok pulau mulai dari hotel, motel, resort, villa, restaurant, maupun berbagai jasa akomodasi yang menawarkan berbagai produk menarik. Mayoritas karyawan yang bekerja dalam industri ini sendiri adalah pekerja milenial (Dhevabanchachai \& Muangasame, 2013), serta merupakan penduduk lokal Bali yang terkenal dengan keramahtamahannya. Hal ini membuat pekerjaan yang berhubungan dengan melayani orang terasa lebih mudah dan menyenangkan.

Hospitality industry merupakan perusahaan dalam bidang jasa yang memiliki tuntutan yang sangat tinggi. Seseorang yang bekerja dalam hospitality industry biasanya menganggap bahwa pekerjaan mereka selain mernarik, juga menantang, memiliki waktu kerja yang panjang, serta memiliki standar yang tinggi atas kepuasan pelanggan. Tingginya tuntutan dalam sektor bisnis ini biasanya tidak diimbangi dengan kemajuan pengembangan karier yang baik sehingga tidak jarang karyawan berpindah-pindah pekerjaan demi meningkatkan pengembangan karier masing-masing. Khususnya di Bali, sektor bisnis ini memiliki lapangan pekerjaan yang luas di seluruh pulau sehingga berpindah-pindah pekerjaan merupakan hal yang sangat mudah. Tidak jarang karyawan yang bekerja dalam bidang ini tidak memiliki pemahaman yang benar mengenai karier serta peluang kesuk-sesan 
karier yang didapatkan dalam perusahaan. Seperti yang dijelaskan oleh Cicek, Karaboga dan Sehitoglu (2016), pekerja milenial rela meninggalkan satu organsiasi ke organisasi lain demi kepentingan kariernya dan mewujudkan kesuksesan karier.

Berdasarkan hasil dari penelitian ini ditemukan bahwa kesuksesan karier seorang pekerja milenial dapat diciptakan melalui adanya persepsi pengembangan karier yang baik dan juga komitmen karier yang dimiliki masing-masing pekerja. Pengembangan karier dalam perusahaan merupakan manajemen sumber daya manusia yang paling penting. Perusahaan khususnya hospitality industry dapat berperan dalam kesuksesan karyawannya melalui berbagai kesempatan pengembangan karier yang diciptakan dalam perusahaan. Persepsi karyawan merupakan cerminan dari rencana dan implementasi program pengembangan karier dalam perusahaan. Pengembangan karier yang dipersepsikan secara positif oleh pekerja milenial mengindikasikan bahwa adanya dukungan yang diberikan perusahaan dalam mengembangkan karier karyawan. Selain itu, persepsi pengembangan karier yang positif menunjukan kesesuaian antara dukungan yang diberikan perusahaan dengan harapan karier karyawan.

Indusri hospitality saat ini kewalahan untuk menarik dan mempertahankan sumber daya manusia yang paling berkualitas. Tanpa perubahan dengan system manajemen sumber daya manusia yang ada dalam perusahaan, tantangan tersebut akan terus diperparah dan mengancam keberlangsungan perusahaan (Ho, Ahn \& Law, 2015). Pengembangan karier yang dipersepsikan positif oleh pekerja milenial dapat mengisyaratkan bahwa perusahaan dapat membantu karyawan untuk membangun kariernya dan menjadi lebih ahli dalam bidang kariernya masing-masing. Semakin ahli seseorang, semakin berkembang pula wawasan dan keterampilannya. Karyawan yang memiliki keterampilan yang sesuai dengan pekerjaannya dapat menunjukan peforma yang sejalan untuk meningkatkan tujuan perusahaan. Karyawan yang memiliki peforma yang baik dalam perusahaan cenderung lebih mudah untuk mencapai kesuksesan karier dibandingkan dengan karyawan yang kurang terampil (Rahmawati, 2013).

Persepsi pengembangan karier merupakan hal penting, namun karyawan juga diharapkan memiliki komitmen terhadap karier yang mereka jalani. Komitmen karier dikonsepkan sebagai motivasi seseorang untuk bekerja dalam bidang karier yang menjadi pilihannya (Hall, 1976). Karyawan yang memiliki komitmen karier akan lebih menunjukan keinginan untuk belajar dengan tujuan untuk meningkatkan peforma kerja dalam perusahaan (Tharanganie, 2013). Hal ini disebabkan oleh komitmen karier mendorong karyawan untuk melengkapi dirinya dalam menghadapi perubahan lingkungan kerja. Lingkungan kerja dalam industri hospitality yang dinamis mengharuskan karyawan untuk melengkapi diri dengan pengetahuan terkini agar bisa bersaing dilapangan. Seseorang yang berkomitmen terhadap kariernya akan lebih terbuka untuk mengikuti pengembangan, pelatihan, dan memperoleh pengetahuan sejalan dengan kariernya, sehingga dapat membantunya untuk maju dalam kariernya. Besarnya usaha yang dilakukan seseorang untuk kemajuan kariernya dapat menuntunnya pada peforma kerja yang baik, sehingga nantinya dapat mencapai kesuksesan karier (Sultana et al, 2016).

Berdasarkan temuan penelitian ini disimpulkan bahwa prediktor yang paling berperan dalam memprediksi kesuksesan karier adalah komitmen karier yaitu 
sebesar 25.70\%, dibandingkan dengan persepsi pengembangan karier sebesar 19.4\%. Hal ini menunjukan bahwa kesuksesan karier lebih dapat diwujudkan jika pekerja milenial memiliki komitmen yang tidak lain merupakan motivasi dari dalam dirinya. Komitmen karier dijelaskan sebagai upaya pengembangan yang dilakukan seseorang guna memenuhi tujuan kariernya (Colarelli \& Bishop, 1990). Seseorang yang berkomitmen ditandai dengan adanya kelekatan, identifikasi diri serta keterlibatan individu dalam mencapai tujuan karier secara personal. Sejauh mana seseorang berkomitmen terhadap kariernya dapat direfleksikan oleh ketekunannya dalam mengejar tujuan karier terlepas dari rintangan dan kesulitan yang dihadapi. Seseorang yang dapat menyelaraskan tindakan dengan tujuan dan nilai-nilai yang ingin dicapai, maka akan semakin besar kemungkinan untuk berhasil mencapai kesuksesan (Duckworth \& Gross, 2014).

Alzyoud (2017) juga menemukan hal serupa dimana komitmen karier merupakan cerminan motivasi karyawan dalam bekerja. Motivasi dapat diartikan sebagai proses yang menjelaskan intensitas, arah, dan ketekunan usaha untuk mencapai suatu tujuan. Hal ini juga sesuai dengan teori yang dikemukakan oleh Frederick Irving Herzberg yang menyebutkan bahwa terdapat dua factor yang mendorong seorang karyawan dalam bekerja yaitu faktor motivasi dari luar atau hygiene dan motivasi yang berasal dari dalam diri atau motivator. Herzberg sendiri menjelaskan bahwa faktor motivator akan memunculkan motivasi yang lebih kuat dalam diri karyawan dibandingkan dengan faktor hygiene. Karyawan yang termotivasi dari dalam dirinya menganggap bahwa dengan bekerja mereka mendapat kepuasan tersendiri, sehingga pekerjaan atau karier memiliki nilai psikologis yang dirasakan sebagai manfaat tambahan bagi pemenuhan diri. Selain itu, seseorang yang termotivasi dari dalam diri biasanya lebih berhasil dibandingkan dengan seseorang yang membutuhkan dorongan dari luar (Robbins \& Judge, 2008).

Komitmen karier juga merupakan hal yang sangat dibutuhkan untuk bekerja dalam bidang hospitality. Tingginya tuntutan dalam industri ini menyebabkan dibutuhkannya karyawan yang terampil di bidang yang sejalan. Biasanya karyawan yang bekerja dalam industri ini adalah mereka yang memiliki latar belakang pendidikan yang sejalan serta memiliki pengalaman yang cukup untuk dapat menampilkan peforma yang baik dalam perusahaan. Maka dari itu, karyawan khususnya pekerja milenial dituntut untuk memiliki komitmen terhadap karier yang dijalani agar dapat mewujudkan kesuksesan karier. Karyawan yang berkomitmen dapat mengidentifikasikan dirinya terhadap pilihan karier serta memiliki perencanaan terhadap tujuan karier yang ingin dicapai. Hal ini membuatnya lebih terbuka untuk memperoleh pengetahuan yang sejalan guna bersaing dalam organisasi, yang nantinya akan mengarahkannya pada kesuksesan karier secara nyata seperti kenaikan jabatan atau tambahan kompensasi. Selain itu, karyawan yang berkomitmen juga dapat mengatasi dengan segala kesulitan dan tuntutan yang ada dalam hospitality industry, sehingga karyawan dapat bekerja dengan bahagia dan menimbulkan kepuasan kerja yang merupakan indikator dari kesuksesan karier subjektif.

Peran komitmen karier yang lebih besar terhadap kesuksesan karier juga dapat dijelaskan dengan karakteristik subjek dalam penelitian ini yaitu pekerja milenial yang merupakan masyarakat Bali. Pemilihan karier masyarakat Bali sendiri umumnya memilih untuk bekerja dalam sektor hospitality. Selain disebabkan oleh maraknya perusahaan berjenis hospitality, masyarakat Bali juga memaknai pekerja- 
annya dengan berbeda. Pemilihan karier seseorang biasanya ditandai dengan ketertarikannya dalam bidang karier tertentu yang merepresentasikan identitas pribadi atau citra diri (Leong, Rosenberg \& Chong, 2014). Masyarakat Bali yang sudah terkenal dengan keramahtamahannya biasanya juga akan memilih jenis karier yang memiliki unsur keramahtamahan didalam-nya. Bekerja dengan karakteristik yang sesuai dengan citra diri seseorang dapat menimbulkan motivasi dalam diri yang tidak lain merupakan komitmen individu terhadap pekerjaannya.

Hal ini juga sesuai dengan karakteristik pekerja milenial yang akan menunjukan kinerja yang optimal jika bekerja dengan minat karier yang sesuai (Bencsik, HorvathCsikos, Juhasz, 2016). Rosyadi (2017) juga mengemukakan bahwa pemilihan karier yang sesuai akan mencerminkan kompetensi yang dimiliki individu, passion atau gairah dan keleluasaan berkarya. Seseorang yang termotivasi dari dalam dirinya akan cenderung terikat dengan karier yang ia jalani dan berusaha untuk memperoleh pengalaman yang serupa untuk meningkatkan keterampilannya. Besarnya usaha yang dilakukan seseorang biasanya akan berimbang dengan perasaan positif terhadap karier yang dijalani, sehingga seseorang cenderung untuk menjalani pekerjaan dengan bahagia dan puas yang merupakan indikator dari kesuksesan karier subjektif.

Tingginya komitmen karier yang dimiliki masyarakat Bali terhadap kariernya dalam bidang hospitality dapat dijelaskan dari pemaknaan karier yang dimliki masing-masing individu. Masyarakat Bali memaknai pekerjaan dalam bidang hospitality dengan cara yang berbeda. Makna karier dijelaskan sebagai sebuah pemaknaan mengenai pekerjaan atau karier yang signifikan dengan individu serta memiliki nilai-nilai yang positif (Lysova, Allan, Dik, Duffy, \& Steger, 2017). Seorang individu dapat memberikan makna pada pekerjaannya berdasarkan keartian dari pekerjaan tersebut pada dirinya (Sumaryono, 2016). Masyarakat Bali memberikan makna pada kariernya di bidang hospitality sebagai pekerjaan yang berarti dan sesuai sehingga menimbulkan rasa bahagia dalam menjalaninya. Suatu pekerjaan yang menggambarkan citra diri seseorang akan memiliki makna yang lebih dari hanya sekedar bekerja. Hal ini juga membuatnya memiliki keterlibatan tinggi atas karier yang dipilihnya maka akan menunjukan segala usaha untuk menampilkan kinerja yang optimal (Sumaryono, 2016).

Bekerja dalam bidang karier hospitality dapat menggambarkan citra diri masyarakat Bali, sehingga karyawan memiliki komitmen yang kuat terhadap kariernya. Seseorang yang memiliki komitmen terhadap karier dan pekerjaannya akan lebih menghargai pekerjaan dibandingkan dengan orang yang tidak memiliki komitmen. Ia akan bekerja dengan sepenuh hati terlepas dari kesulitan dan rintangan yang dialaminya, sebab kesulitan dan tantangan inilah yang nantinya akan menjadi makna karier dalam mengolah keterampilannya dan proses pengembangan diri individu (Sumaryono, 2016). Komitmen yang dimiliki individu terhadap pilihan karinya dapat menimbulkan kesuksesan karier secara subjektif. Seperti yang dikemukakan oleh Earl (2014), bekerja dalam bidang yang sesuai dengan citra diri seseorang dapat menimbulkan rasa kepuasan dalam bekerja. Besarnya rasa kepuasan kerja seseorang yang merupakan indikator dari kesuksesan karier subjektif dapat dicapai jika seseorang memiliki pekerjaan atau karier di bidang yang sejalan.

Berdasarkan katergorisasi skor penelitian didapatkan hasil bahwa skor responden dalam varibael lainnya yaitu persepsi pengembangan karier juga berada pada kategori tinggi. Hal ini dapat dijelaskan dengan karakteristik responden dalam 
penelitian ini yang mayoritas merupakan pekerja milenial yang memiliki masa kerja dari 2 tahun hingga 5 tahun yaitu sebanyak 143 orang atau $71.7 \%$. Hitka dan Balazova (2015) menjelaskan bahwa terdapat perbedaan motivasi kerja berdasarkan tingkat senioritas atau lama bekerja seseorang. Karyawan yang memiliki masa kerja yang tergolong baru biasanya akan menampilkan motivasi kerja yang lebih tinggi dibandingkan dengan karyawan yang memiliki masa kerja lama. Tingginya motivasi kerja seseorang biasanya berbanding lurus dengan peningkatan peforma kerja, sehingga karyawan baru biasanya memiliki motivasi yang tinggi untuk menampilkan peforma kerja yang baik (Nduka, 2016).

Pengembangan karier dalam suatu organisasi biasanya diberikan oleh karyawan yang memiliki peforma kerja yang baik, sehingga karyawan tersebut akan memiliki peluang yang besar dalam mendapatkan pengembangan karier dibanding karyawan yang memiliki peforma kerja biasa saja. Hal inilah yang menyebabkan karyawan yang memiliki masa kerja yang tergolong baru dapat mempersepsikan pengembangan karier pada tempat kerjanya dengan positif, sebab karyawan baru biasanya cenderung mendapat lebih banyak pengembangan karier dibandingkan dengan karyawan yang memiliki masa kerja yang panjang dan kurang termotivasi.

\section{Kesimpulan}

Berdasarkan hasil penelitian dan analisis data yang telah dilakukan, maka dalam penelitian ini dapat ditarik kesimpulan sebagai berikut: persepsi pengembangan karier dan komitmen karier secara bersama-sama memiliki peran dalam meningkatkan variabel kesuksesan karier pada pekerja milenial di hospitality industry sebesar $44.8 \%$. Sedangkan jika dilihat secara parsial variabel persepsi pengembangan karier memiliki peran sebesar $19.4 \%$ dan variabel komitmen karier sebesar 25.70\% terhadap kesuksesan karier. Berdasarkan analisis data demografi ditemukan bahwa tidak terdapat perbedaan kesuksesan karier antara jenis kelamin. Kategorisasi data penelitian menunjukkan bahwa skor variabel persepsi pengembangan karier berada pada kategori tinggi, artinya bahwa responden mempersepsikan pengembangan karier yang ada dalam perusahaan secara baik. Begitu juga pada variabel komitmen karier berada pada kategori tinggi, artinya responden memiliki komitmen karier yang tinggi. Selanjutnya pada variabel kesuksesan karier juga berada pada kategori tinggi, yang artinya bahwa sebagian besar responden memiliki persepsi kesuksesan karier yang baik.

\section{Saran}

Berdasarkan hasil penelitian yang dilakukan maka saran yang dapat diberikan yaitu bagi organisasi dapat menerapkan pengembangan karier yang sesuai dengan karakteristik dan harapan karyawan, sehingga karyawan mendapatkan keahlian dan keterampilan yang sesuai untuk dapat diterapkan dalam perusahaan. Pengembangan karier hendaknya diselaraskan dengan tujuan organisasi sehingga dapat berkontribusi untuk kemajuan perusahaan. Setiap program pengembangan karier yang dilaksanakan dalam perusahaan harus diketahui oleh seluruh karyawan dan dijalankan dengan objektif, sehingga setiap karyawan mendapatkan kesempatan yang sama sesuai dengan kualifikasi yang disyaratkan. Perusahaan juga dapat menumbuhkan komitmen karier yang dimiliki karyawan dengan cara meningkatkan pemahanan dan keterampilan karyawan dalam perencanaan karier masa depan dengan pelatihan berupa Career Commitment Training. Berdasarkan analisis tambahan ditemukan bahwa tidak 
terdapat perbedaan kesuksesan karier antara pekerja milenial laki-laki dengan perempuan, sehingga perusahaan diharapkan untuk tidak membedakan jenis kelamin dalam proses perekrutan tenaga kerja maupun dalam segala aktivitas yang ada didalam perusahaan.

Saran yang dapat diberikan untuk pekerja milenial di hospitality industry yaitu pekerja milenial hendaknya ikut berperan pada program pengembangan karier yang ditawarkan dalam perusahaan agar lebih termotivasi untuk menunjukan peforma yang baik guna mewujudkan kesuksesan karier dalam perusahaan. Melihat hasil dari analisis yang memaparkan tingginya peran komitment karier terhadap kesuksesan karier, maka pekerja milenial dirasa perlu memiliki komitmen terhadap bidang karier masing-masing. Hal ini dapat dilakukan dengan cara memiliki perencanaan terhadap tujuan karier masa depan yang spesifik, terlibat dalam pengembangan karier yang sesuai, serta melakukan investasi pada kegiatan-kegiatan yang dapat menambah keterampilan sesuai dengan bidang karier.

Saran yang dapat diberikan untuk peneli-tian selanjutnya yaitu untuk dapat meneliti variabel-variabel lain diluar variabel dalam penelitian ini yang mungkin dapat berperan lebih besar dalam meningkatkan kesuksesan karier seseorang. Peneliti selanjutnya juga dapat mengambil lebih banyak jumlah subjek dari beragam perusahaan yang ada dalam bidang hospitality, sehingga hasil penelitian dapat merepresentasikan lebih beragam bidang dalam bidang hospitality. Berdasarkan data demografi dalam penelitian ini, didapatkan hasil bahwa tingkat kesuksesan karier pekerja milenial yang tinggi dengan mayoritas responden penelitian yang memiliki masa kerja 2 hingga 5 tahun. Penelitian selanjutnya dapat meneliti karyawan yang memiliki masa kerja lebih dari 5 tahun untuk melihat tingkat kesukE-JOURNAL GAMAJOP sesan karier pekerja milenial yang telah memiliki masa kerja karier yang panjang. Selain itu, penelitian selanjutnya hendaknya mengambil responden yang memiliki karakteristik demografi dalam tingkatan yang sejenis, seperti pendidikan dan masa kerja, sehingga hasil penelitian nantinya dapat disimpulkan dengan lebih tepat.

\section{Daftar Pustaka}

Aiken, L. R. (1985). Three coefficients for analyzing the reliability and validity of ratings. Educational and Psychology Measurement, 45, 131-142. doi: $\underline{10.1177 / 0013164485451012}$

Alzyoud, A. A. Y. (2017). The predictors of career success. International Review of Management and Marketing, 7(2), 22-26.

Amstrong, M. \& Taylor, S. (2014). Amstrong's handbook of human resources management practice. United Kingdom: Kogan Page.

Anafarta, A. \& Apaydin, C. (2016). The effect of faculty mentoring on career success and career satisfaction. Journal International Education Study, 9(6), 22-31. doi: 10.5539/ies.v9n6p22

Astina, I. N. G., Bendesa, I. K. G. \& Wiranatha, A. S. (2017). The employees quality of services based on the Balinese local wisdoms at non star-rate hotels in bali. Journal of Tourism, 4(1), 55-61. doi: 10.24922/eot.v4i1.30169

Bencsik, A.; Horvart-Csikos, G. \& Juhasz, T. (2016). $\mathrm{Y}$ and $\mathrm{Z}$ generation at workplace. Competitiveness Journal, 8(3), 90-106. doi: 110.7441/joc.2016.03.06

Blau, G. J. (1985). The measurement and prediction of career commitment. Journal of Occupational and Organizational Psychology, 58(4), 277-288. doi: 10.1111/j.2044-8325.1985.tb00201.x

Carson, K. G. \& Bodeian, A. G. (1994). Career commitment: construction of a measure and examination of its psychometric properties. Journal of 
Vocational Behavior, 44(3), 237-262. doi: $\underline{10.1006 / j v b e .1994 .1017}$

Cicek, I., Karaboga, T. \& Sehitoglu, Y. (2016). A new antecedent of career commitment: work to family positive enhancement. Journal Social and Behavioral Science, 229, 417-426. doi: 10.1016/j.sbspro.2016.07.152

Colarelli, S. M. \& Bishop, R. D. (1990). Career commitment: function correlates, and management. Journal Group and Organization, 15(2), 158-176. doi: $10.1177 / 105960119001500203$

Davis, K. \& Werther, W. B. (1996). Human resources and personnel management. Singapore: McGraw-Hill.

Deal, J. J. (2007). Retiring the generation gap: how employee young and old can find common ground. San Fransisco: JosseyBass.

Devabanchachai, N. \& Muangasame, K. (2013). The preferred work paradigm for generation $y$ in the hotel industry: a case study of the international tourism and hospitality international programme, thailand. International Education Studi, 10(6), 27-38. doi: 10.5539/ies.v6n10p27

Dubrin, A. J. (1982). Contemporary applied management. Texas: Plano.

Duckworth, A. \& Gross, J. J. (2014). Selfcontrol and grit: related but separable determinants of success. Psychological Science, 23(5), 319-325. doi: $\underline{10.1177 / 0963721414541462}$

Earl, K. A. (2014). Interest congruence and job satisfaction: a quantitative review. Thesis. Master of Science in Educational Psychology University of Illinois.

Gursoy, D., Chi, C. G. \& Karadag, E. (2013). Generational differences in work values and attitudes among frontline and service contact employees. International Journal of Hospitality Management, 32(3), 40-48.doi: 10.1016/j.ijhm.2012.04.002
Hall, D. T. (1996). The career is dead-long live the career: a relational approach to careers. San Francisco: Jossey-Bass.

Hall, D. T. (1976). Careers in organizations. California: Goodyear.

Hitka, M. \& Balazova, Z. (2015). The impact of age, education and seniority on motivation of employees. Bussiness Theory and Practice, 16(1), 113-120.doi: $\underline{10.3846 / \text { btp. } 2015.433}$

Ho, G. K. S., Ahn, M. \& Law, R. (2015). Generation $\mathrm{Y}$ hospitality management students attitude toward the industry: an asian perspective. Asian Journal of Tourism and Hospitality, 8(9), 40-51.

Judge, T. A., Cable, D. M., Boudreau, J. W. \& Bretz, R. D. J. (1995). An empirical investigation of the predictor of executive career success. Journal Personnel Psychology, 48(3), 485-519. doi 10.1111/j.1744-6570.1995.tb01767.x

Judge, T. A., \& Hurst, C. (2008). How the rich (and happy) get richer (and happier): relationship of core selfevaluations to trajectories in attaining work success. Journal of Applied Psychology, 93(4), 849-863. doi: 10.1037/0021-9010.93.4.849

Koekemoer, E. (2014). An explorative study on factors influencing the career success of management employees. Journal of Industrial Psychology, 40(2), 1-10. doi: 10.4102/sajip.v40i2.1204

Kong, H., Wang, S. \& Fu, X. (2015). Meeting career expectation: can it enhance job satisfaction of generation Y? International Journal of Contemporary Hospitality Management, 27(1), 147-168. doi: 10.1108/IJCHM-08-2013-0353

Leong, F. T.; Rosenberg, S. D. \& Chong, S. (2014). A psychometric evolution of Schein's (1985) Career Orientations Inventory. Journal of Career Assessment, 22(3), 524-538. doi: $\underline{10.1177 / 1069072713498685}$

Lysova, E. I.; Allan, B. A.; Dik, B. J.; Duffy, R. D. \& Steger, M. F. (2017). Fostering 
meaningful work in organization: a multilevel review and integration. Journal of Vocational Behavior, 110(B), 374-389. doi: 10.1016/j.jvb.2018.07.004

Malute, D. I. (2012). Dinamika kesuksesan karier job-hopper pada boundaryless career. Thesis Magister Psikologi. Universitas Gadjah Mada.

Mooney, S. K., Harris, C. \& Ryan, I. (2016). Long hospitality careers-a contradiction in terms? International Journal of Contemporary Hospitality Management, 28(11), 2589-2608. doi: 10.1108/IJCHM04-2015-0206

Nduka, O. (2016). Employee motivation and performance. Thesis. Centria University.

Ndung'u, C. N. (2016). The effect of mentoring on employee career success in nairobi's star rated hotels. Thesis. University of Nairobi.

Ng, T. M. H. \& Feldman, D. C. (2014). Subjective career success: a meta analytic review. Journal of Vocational Behavior, 85(2), 169-179. doi: 10.1016/j.jvb.2014.06.001

Noviani, E. (2018). Kesejahteraan psikologis pada wanita karier ditinjau dari dukungan sosial keluarga dan kesuksesan karier. Thesis Magister Psikologi Profesi. Universitas Gadjah Mada.

Pasha, A. T., Hamid, K. A. \& Shahzad, A. (2017). Mediating role of career commitment in the relatinship of promotional opportunities, reward and career success. Journal of Internet Banking and Commerce, 13(1), 185-199. doi: 10.18187/pjsor.v13i1.1587

Rachman, E. \& Jakob, E. (2016). Experd: character building and training. Jakarta: Kompas.

Rahmawati, A. (2013). Hubungan antara persepsi terhadap pengembangan karier karyawan dengan loyalitas kerja CV. sinar abadi. Skripsi. Universitas Muhammadiyah Surakarta.

Robbins, S. P. \& Judge, T. A. (2008). Perilaku organisasi (buku 1). Jakarta: Salemba Empat.

Rosyadi, T. I. (2017). Pengaruh pilihan karier (career choice) dan kesejahteraan (weel-being) terhadap kinerja karier (career performance). Thesis. Magister Psikologi Profesi Universitas Gadjah Mada.

Sugiyono. (2007). Statistika untuk penelitian. Bandung: Alfabeta.

Sultana, R., Yousaf, A., Khan, I. \& Saeed, A. (2016). Probing the interactive effects of career commitment and emotional intelligence on perceived objective/ subjective career success. Business and Economic-Management Journals, 45(4), 724-742. doi: 10.1108/PR-11-2014-0265

Sumaryono. (2016). Pengaruh makna karier dan individual well-being terhadap kinerja karier. Disertasi. Program Pascasarjana Universitas Padjajaran Bandung.

Tharanganie, M. G. (2013). The influence on career commitment on motivation to learn and motivation to transfer. Asian Journal of Bussiness and Management, 1(3), 78-86.

Utami, N. P. (2018). Intensi turnover ditinjau dari komitmen karier dan kepemimpinan transformational pada youth urban workers. Tesis. Program Studi Magister Psikologi Profesi Fakultas Psikologi Universitas Gadjah Mada.

Zemke, R., Raines, C. \& Filipczak, B. (2000). Generation at work: managing the clash of the veterans, boomers, xers, and nexters in your workplace. New York: American Management Association. 